\title{
Perceived Role of Rural Roads in Supporting and Enhancing Rural and Agricultural Development in Mwanza Region, Tanzania
}

\author{
Mukole Kongolo \\ Department of Economics \\ St Augustine University of Tanzania (SAUT) \\ Mwanza, Tanzania \\ Tel: 255-714-130-718Ｅ-mail: gilkoka8@ gmail.com
}

Received: March 4, 2020

Accepted: March 25, 2020

Published: May 20, 2020

doi:10.5296/iss.v8i1.17067

URL: http://dx.doi.org/10.5296/iss.v8i1.17067

\begin{abstract}
The aim of this study was to reassess the important role of rural roads in supporting and enhancing agricultural and rural development. The study covered seven districts (units) of $35,187 \mathrm{sq} \mathrm{km}$, with a total population of 2,772,509 (2013 est) in the region. The analysis is descriptive and it is based on secondary data using tables and graphs. The emphasis was to characterise important role rural roads can play in facilitating the movements of goods and services in rural areas. The findings revealed that rural roads in the region are in poor conditions, which influenced the cost of transporting farm produce from rural to urban areas. The study concluded that improved rural roads will benefit more small farmers and individuals residing in rural areas. The regional government should be equipped with finance, personnel and equipment to manage and maintain existing rural roads to ensure effective movement of goods and services in the region. The study suggested that existing rural road conditions need improvement to enhance development in the region. Both national and regional governments should embark on various policies of upgrading and maintaining rural roads to support and accelerate rural development in Mwanza region.
\end{abstract}

Keywords: Rural infrastructure, Rural roads maintenance, Rural transport, Agricultural and rural development, Poverty alleviation, Mwanza region, Tanzania 


\section{Introduction}

Rural road networks in rural Africa consist more often of gravel roads as much of the trunk road network have been unsealed. In Tanzania, for example, only some $7 \%$ of the entire classified road network is bituminized (World Bank, 2011). Rural roads are often a lifeline for rural communities. Research has shown that there is a positive strong correlation between lack of access to basic infrastructure and poverty. Villages provided with road access produced more than they did before (Banjo et al., 2012). Without access to roads, rural community's ability to take advantage of surplus crop production and employment opportunities is severely reduced (Escobal \& Ponce, 2002). Rural roads play critical role in the provision of physical access, physical access further plays an important role in reaching a number of the Millennium Development Goals (Barret et al., 2001). The problem with gravel roads is that they often deteriorate rapidly, especially in the wet season, disrupting transport services and access to health centres and markets when it is most needed (World Bank, 2011). There is increased expectation amongst the rural poor that governments will provide and maintain roads in a condition that facilitate all-weather access and regular transport services (Donngos et al., 2007).

Rural road networks also tend to be large and complex; they are often 2 to 3 times the size of the main and regional networks, but carry only $10 \%$ of the traffic in vehicle kilometers (IFRTD, 2006). Foot, animal and bicycle paths also feed into rural roads; in turn rural roads link markets and peri-urban hubs (Raballand, 2010). Rural roads include secondary roads and any other roads used by communities in urban and rural areas than main roads, and are managed by various municipalities, often they are managed by local governments and communities. They account for about $80 \%$ of the total road network lengths but carry only $20 \%$ of the total motorized traffic. They provide access to the majority of population in most rural areas in the country. Traffic in these roads often consists of a majority of non-motorized or intermediate means of transport and pedestrians. Management and financing arrangements for these roads are often scarce and sometimes not in existence (Buys et al., 2006).

Gravel roads deteriorates rapidly if not maintained by timely grading and re-gravelling. Gravel roads are reconstructed or rehabilitated at frequent intervals often with little in the way of lasting improvement (World Bank, 2011). It is estimated that in South Africa alone some 150 million cubic metres of gravel are consumed annually. Thus, despite the best intentions of governments to provide roads with a sealed surface, funding for upgrading is often limited. For countries such as Tanzania and many others, unsealed roads will remain a significant part of the network for many years to come (World Bank, 2011). A major constraint with developing and maintaining rural roads is the fact that they are, unfortunately, rural. The areas where they are needed are often difficult to access, logistics are complicated, local contracting capability is limited, engineers are few and far between, and younger engineers especially, are not keen to leave the urban environment (World Bank, 2011). Since rural areas have been the growth engine of any country, both food supply and population are the custodians of the rural areas and ecosystems. Those planning for rural development should be familiar with both its complexities and interconnecting priorities, including the needs to know how the provision of rural roads fits into the larger goals of rural development 
(Jacoby, 2000). As a result of limited capability and the attraction of low upfront capital costs (mortgaged against the future maintenance costs), over $90 \%$ of the road network remains unpaved in some developing countries, mostly graveled, and the problem is not just in the logistics of building good roads but maintaining them too (IFRTD, 2005). Without physical access, rural communities face obstacles in social services delivery such as health, education, and related social services (Escobal \& Ponce, 2002). The purpose of this study is to re-assesses important role of rural roads in contributing to agricultural and rural development in the study area.

\subsection{The Problem}

Agricultural production by small-scale farmers in Tanzania has its final destination to the main centres, where it is sold to various local markets and individuals. Although today's increasing virtual connectivity as a result of the new communication means, a reliable and good road network remains vital. There is a strong positive correlation between a country's economic development and the quality of its road network (Jacques \& Wally, 2012). Accordingly, by 2011, Tanzania lagged behind Uganda and Kenya in terms of development of its road network for the following reasons:

(1) The road network in Tanzania is three times less dense, as given by the number of kilometers of road per 1,000 Sq km of land mass than in Uganda and Kenya. (2) There are 7.5 $\mathrm{km}$ of paved road per 1,000 Sq km of land mass in Tanzania, while this ratio is 82 and 19.7 for Uganda and Kenya respectively. (3) Only $5.8 \%$ of the national roads network is considered in good and reliable condition in Tanzania as opposed to $20.7 \%$ and $11.0 \%$ in Uganda and Kenya respectively.

Still, Jacques \& Wally (2012) argued that not only is the road coverage in Tanzania insufficient, but where they do exist they are either in poor conditions or are totally impassable, especially during the rainy season. Households, especially those in remote areas, experience difficulties transporting their goods, travelling from one point to another within the country or even catching up on new developments. Temu et al. (2005) expressed that road density for unpaved roads ranges across regions from $0.01 \mathrm{~km}$ per $\mathrm{Sq} \mathrm{km}$ in Lindi to $0.07 \mathrm{~km}$ per Sq $\mathrm{km}$ in Mwanza, while paved road density is below $0.011 \mathrm{~km}$ per $\mathrm{Sq} \mathrm{km}$ for most regions. They also said that Tanzania has four major road networks: The Tanzania-Zambia highway traversing Dar-es-salaam, Coast, Morogoro, Iringa and Mbeya regions; the central line, starting from Dar-es-salaam passing through Coast, Morogoro to Dodoma administrative regions; The North Eastern highway, connecting Dar-es-salaam, Tanga, Kilimanjaro and Arusha; and lastly, the Lake Zone network, connecting Mwanza and Mara. Although feeder roads are more important for connecting the majority of rural smallholder agricultural producers to be able to markets goods and services, available data at national level focuses mainly on paved and unpaved trunk roads. Overall, the country has a very low road density, estimated at below 05 $\mathrm{km}$ per sq $\mathrm{km}$. There are $85,000 \mathrm{kms}$ of road comprising: 10,300 highway and trunk roads, 24,700 regional roads, $20,000 \mathrm{kms}$ district roads, $30,000 \mathrm{kms}$ of feeder roads and $20,000 \mathrm{kms}$ are of an unclassified category (Temu et al., 2005). However, rural roads play critical and significant role of ensuring effective movement of rural people and exchange of goods and 
services to stimulate and enhance rural and agricultural development in the country (Adeniyi et al., 2018). The study is organized as follows: section 2 presents literature review; section 3 describes methodology, section 4 presents results and discussions; section 5 provides conclusions and recommendations.

\subsection{Objectives}

This study was aimed at reassessing the impact of rural roads with a view to determining their contributions to agricultural and rural development in Mwanza region. The overall objective of the study was to re-emphasise the importance of rural roads in supporting and enhancing agricultural and rural development in the study area. In order to fulfill this objective, the following specific objectives were considered:

- to highlight the importance of rural roads in supporting and enhancing rural and agricultural development,

- to examine the existing conditions of rural roads and transport in the study area;

- to examine government contribution to rural roads development; and

- to identify the various challenges facing rural roads in the region.

Given the study objectives, the following research questions were explored:

1) Why is it important to manage and improve rural roads?

2) What is the impact of improved rural roads on regional economy?

3) Is improvement of rural roads a good strategy for agricultural and rural development?

It was also hypothesised that both small and large farmers represent the hub of socio-economic development. They serve as the answer to job creation for the majority of the unemployed poor people. Therefore, it is in the study's opinion that the answers to these questions will, to some extent, fill the gaps on the role of rural roads for agricultural development in the study area.

\subsection{Limitations of the Study}

In line with the aim of this study, it was decided to align its development and discussion strictly to the role of rural roads in promoting, sustaining and enhancing conducive socio economic development opportunities in rural Tanzania. That is, to the research problem under investigation with emphasis on the following: (i) The importance of rural roads for food production and distribution in the region; (ii) Focus on rural mobility; and (iii) Improving, managing, maintaining or constructing of new rural roads.

\section{Literature Review}

Some important points on the relevance of rural roads for agricultural and rural development are presented in this section. Cook et al. (2017), said that rural roads play an indispensable role in achieving more than half of the rural and agricultural development, that encompass the notion development, to have no one left behind. There are various linkages between rural 
access and its development. Successful scaled-up implementation of rural roads transport will contribute to the realization of sustainable development to alleviate poverty, increased food security, well-being of rural poor, and the empowerment of rural women (Cook et al., 2017). Rural roads contribute positively to improvement of rural people's well-being, increase rural economic activities, including poverty reduction and economic growth Csaki and Tuck (2000). The World Bank (2019), expressed that rural roads play a key role in raising living standards in poor rural areas. Yet despite the consensus on their importance and much anecdotal evidence, there is surprisingly little hard evidence on the size and nature of their benefits. Ale (2013) described the importance of rural roads to agricultural production by smallholder producers. He argued that poor road conditions in rural areas together with high cost of transport of good and services, affect rural people the most by discourage them from improving their farming styles. Asian Development Bank (ADB, 2007), rural roads are critical in addressing, supporting and enhancing rural development and poverty reduction.

Limao and Venable (2000), advocated that the main factors constraining food supply in rural Africa include the extreme state of roads linking to main centres and other such as the cost of fuel. According to Akinola (2007), conditions in most rural areas seem to be poor, because they have been denied improved social and infrastructural facilities as those in urban areas. Lindsay and Kongolo (2014) stated that neglected rural roads increases the cost of maintenance, especially at the end of rainy season. As such, this leads to rural transportation becoming very difficult and costly due to poor conditions in rural areas. Ngezahayo et al. (2019) pointed out that most of the low volume rural roads in Sub-Saharan Africa are unpaved. They are lifelines to the socio-economic factors and well-being of rural communities. In those countries, most of rural roads are made from lateritic or gravel soils. The major challenges that rural roads face in Sub-Saharan Africa include a lack of funding and a lack of engineering input during both construction and maintenance activities (Ngezahayo et al., 2019). Overall, rural roads impact negatively on the lives of the farmers by rendering them very miserable and unable to produce quantity of food needed in urban areas, although food imports have been increasingly playing an important role for the swelling urban population (Sossou et al., 2011). Rural roads play an important role in the provision of physical access in rural areas. Accessibility defines how easy or difficult is it to get to a place. A place is accessible when people can reach there in an acceptable time, and the risk of not getting there on time would be heavy. Rural community's ability to take advantage of surplus crop production and employment opportunities is severely reduced (Tighe, 2006).

\section{Methodology}

This study is a result of information collected through a number of ways, including literature review of previous studies on the topic to have a good understanding of the impact of rural roads for agricultural and rural development. Both narrative and phenomenological methodologies were used, as the researcher wished to describe the perceptions attached to the contributions of the various authors' analysis of the impact of rural roads for rural development (Astalin, 2013). Considering the fact that there can be a number of sources to gather information, the methodology adopted represents relatively a cost effective approach (Corbin \& Strauss, 2008). The first step involved a thorough review of related literatures of 
both published and unpublished reports, rural road studies, policy documents, as well as reports of programs and road infrastructures related studies on Africa. In this way the primary phase of the study made effective use of information already available while conceptualizing this assessment, thus being able to focus on data collection to fill only the key information gaps. The study methodologies were carefully designed to maximize the use of available qualitative information (Corbin \& Strauss, 2008). To address the gap in the literature, this study was conducted to specifically explore the dynamism effects and outcomes of rural roads on rural community in Mwanza, Tanzania (Paudel, 2014). Random sampling method was used in data collection. The participants represented rural people in seven different districts of the study.

\subsection{Conceptual Framework and Research Design}

The design of this study follows qualitative research design, which is a general way of thinking about conducting qualitative research. A qualitative research design is the most flexible of the various experimental techniques, encompassing a variety of accepted methods and structures (Astalin, 2013). As such the design of this study was based on the following three major qualitative research design approaches, namely narrative, phenomenology, and case study. This design helped to investigate the impact of rural roads for agricultural and rural development (Astalin, 2013). From the existing literature there has been an indication of the deep and positive impact of rural roads on rural and agricultural development, for the benefit of the rural community. This suggests that there is no scarcity of research on this issue in terms of the positive outcomes of rural roads (Bogdan \& Biklen, 2006). This study, therefore, is based on the said design including literature review of various studies focusing on the topic (Bogdan \& Biklen, 2006). The aim is to highlight and reinforce the important role rural roads can play in promoting and sustaining rural and agricultural development in rural areas. It is postulated that the interventions in the form of rural roads have wide potential to reach, enhance and support rural activities by rural population who have been marginalized from the benefits of the overall economic growth. This study attempts to address the void and disentangle the degree of such impacts.

\subsection{Data Sources}

This was a desk research review of the available literature on the impact of rural roads in supporting and enhancing rural development. The study was developed based on both secondary and primary data sources, which were obtained through a document methods study (Baker, 1998). Direct observation method was applied while collecting primary data. Households were asked about general information, including changes in the access to different aspects of socio-economic life, such as employment, possession of assets and amenities, production of agricultural goods, use of different social services and ease in access, as well as negative benefits, and mode of transport used (Bogdan \& Biklen, 2006). The rural household survey method covers 102 households selected from the study area. A random sampling method was used to select households in the area. The information collected were analysed using tables and graphs on the Excel programme (Bogdan \& Biklen, 2006). The analysis of these various sources assisted in looking into the various 


\section{$\triangle$ Macrothink}

issues related to rural roads in the region development holistically.

\subsection{Study Area}

The study was conducted in Mwanza region of Tanzania, one of the country's 31 administrative regions with a postcode number 33000. According to the 2012 national census, Mwanza region had a total population of 2,772,509 (URT, 2013). All the seven administrative units of $35,187 \mathrm{sq} \mathrm{km}$ of the study area were included in the study. The regional capital Mwanza lies in the northern part of the country, located between latitude 1030 ' and 30 south of the Equator. Longitudinally the region is located between $31045^{\prime}$ and 340 10' east of Green wich. Regions boardering Mwanza region include Kagera to the west, Shinyanga to the south and south east. The north east boarders Mara region. The northern part of Mwanza is surrounded by the water of Lake Victoria which in turn separates the region from neighbouring countries of Uganda and Kenya (Figure 1) (URT, 2013).

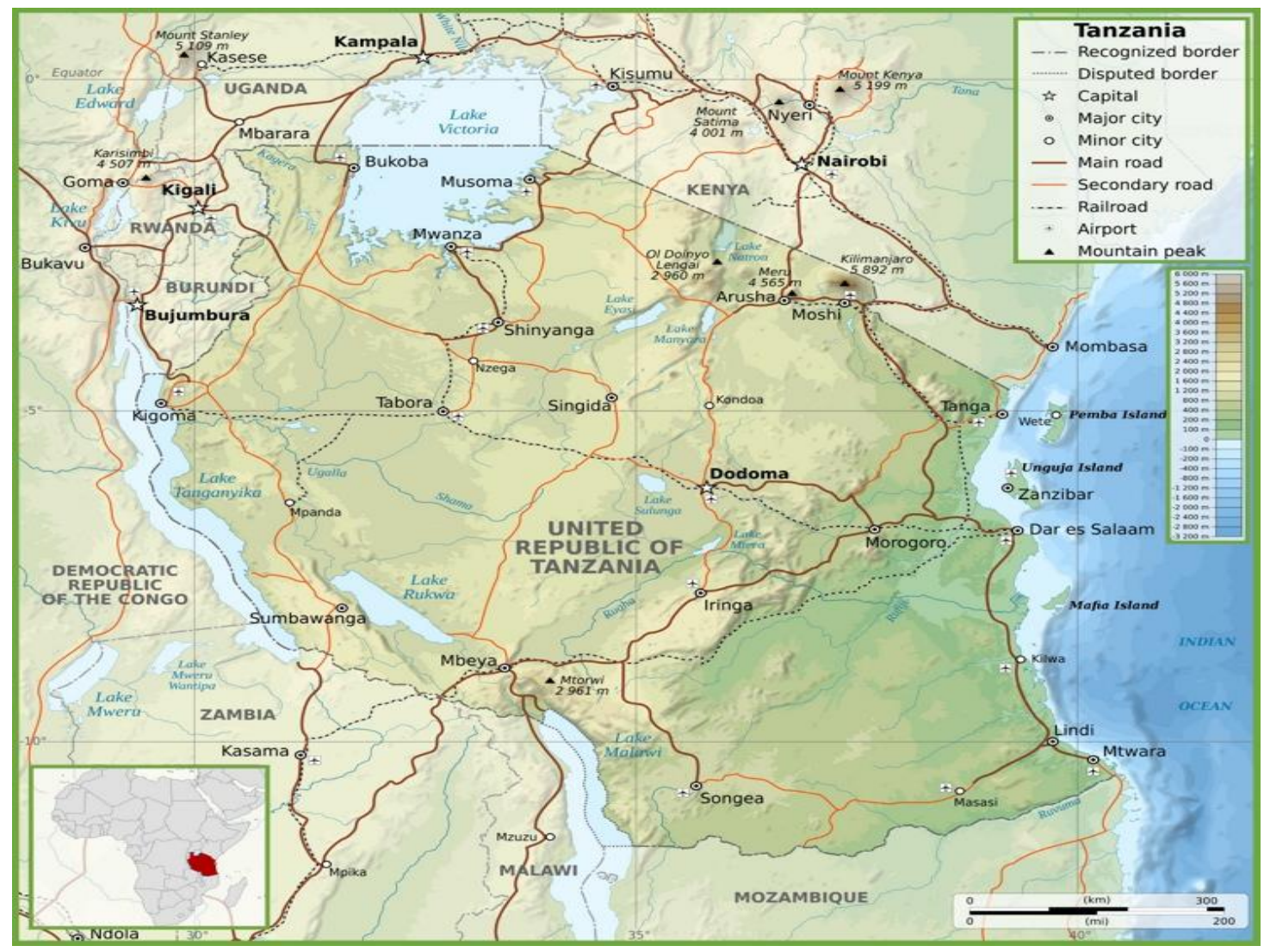

Figure 1. Highways link to trunk, rural and feeder roads in the hinterlands

Figure 1 represents the map of Tanzania with its roads and railway. It also shows the low density of roads and railway lines and how the two serve the same corridors (Temu et al, 2005; JICA, 2012). Mwanza is a relatively small region occupying $2.3 \%$ of the total land area of Tanzania mainland. The region occupies a total of 35,187 sq km., out of this area 20,095 sq 
$\mathrm{km}$. is dry land and 15,092 sq km. is covered by Lake Victoria. The Region's $43 \%$ of surface area is covered by water, the remaining $57 \%$ of surface is a dry land, see Figure 2, Table 1 (URT, 1999).

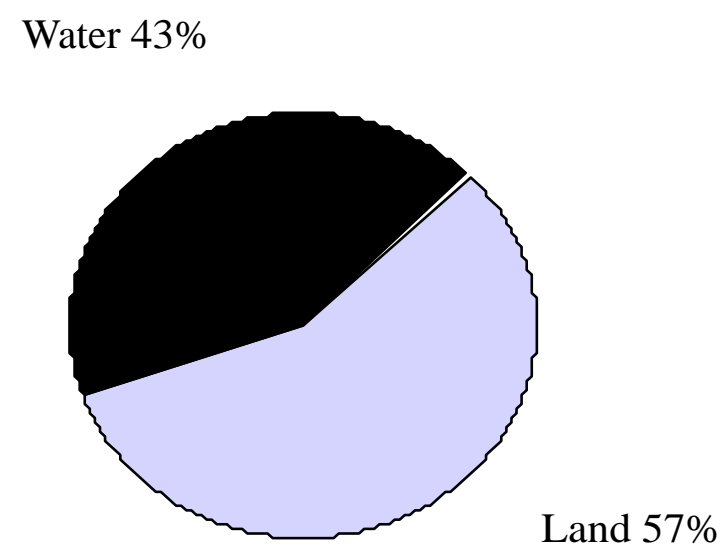

Figure 2. Distribution of surface area, Mwanza region

The region's 7 districts including land area (sq $\mathrm{km})$, water area (sq $\mathrm{km})$, total area (sq $\mathrm{km})$, and total percentage of each district or administrative units are shown in Table 1.

Table 1. Mwanza Region land area and administrative units

\begin{tabular}{|l|c|c|c|c|}
\hline District & $\begin{array}{c}\text { Dry Land (sq km) } \\
\text { Area }\end{array}$ & Water Area $(\mathrm{sq} \mathrm{km})$ & $\begin{array}{c}\text { Total Area } \\
(\mathrm{sq} \mathrm{km})\end{array}$ & $\begin{array}{c}\text { \% of Total } \\
\text { regional Area }\end{array}$ \\
\hline Magu & 3,070 & 1,725 & 4,795 & 13.6 \\
\hline Ukerewe & 640 & 5,760 & 6,400 & 18.2 \\
\hline Geita & 6,775 & 1,050 & 7,825 & 22.2 \\
\hline Sengerema & 3,335 & 5,482 & 8,817 & 25.1 \\
\hline Kwimba & 3,903 & - & 3,903 & 11.1 \\
\hline Misungwi & 1,947 & 175 & 2,122 & 6.0 \\
\hline Mwanza & 425 & 900 & 1,325 & 3.8 \\
\hline Total & 20,095 & 15,092 & 35,187 & 100 \\
\hline
\end{tabular}

Source: URT, 1997.

The main ethnic groups in Mwanza include the Sukuma, Zinza, Haya, Sumbwa, Nyamwezi, Luo, Kurya, Jita and Kerewe. The Sukuma dominate by constituting over $90 \%$ of the population. The rest of the groups constitute in various small proportions. Main crops grown in the region include cotton, cassava, coffee, paddy, sweet potatoes and fruits. Chickens, sheep and cattle are also raised for meat and the diet is also supplemented by fish (URT, 1999). Small-scale farmers 
dominate the production of the staple food crops in rural areas. Women generally handle food production, transport to markets, and sale (Calvo, 1994). However, rural roads impact negatively on their business by rendering them very miserable (Sarkar, 2010).

4. Results and Dicussion

\subsection{The Importance of Rural Roads for Food Production and Distribution in Mwanza}

Agriculture is the most important economic activity in the region, providing food for the fast growing population, raw materials for the agro-industries, foreign exchange and employment for the majority of the rural population. About $85 \%$ of Mwanza regional population depends on agriculture for their livelihood (URT, 1999). In terms of land use, about 4,200 sq. km. of the total land or about $21 \%$ is under small farmers cultivation. The sector aims at raising per capita agricultural output in order to achieve regional self sufficiency in food and surplus for export (URT, 1999). Transport is critical for both economic and non economic activities because growth of agriculture, industrial production and related activities both depend on reliable and efficient transport services for the movement of people and goods and services. The remote areas of the region suffer from long and costly transport system, compared to the region's market center of gravity (URT, 1999).

The region is connected to other parts of the country by road, rail, water and air networks. However, the main concern is the absence of a national road link to the north-eastern area of Arusha, Moshi and Tanga following the extremely bad conditions of the present gravel roads. The absence of such good road has negatively impacted on the development of Mwanza (URT, 1999). The region has a total of $6,349 \mathrm{kms}$ of roads, and out of these $1,437 \mathrm{kms}$ of roads are the responsibility of the region. In addition, there are roads which fall under respective districts' responsibility, totaling $2,635.5 \mathrm{~km}$ of roads, as well as a total of $1,863 \mathrm{kms}$ of feeder roads in the region. The most important roads in the region are trunk roads with a total of up to $413 \mathrm{kms}$ (Figure 3; Table 2). The poor conditions of rural roads have severe consequences on the economic transport of goods and services, and on the overall mobility of the people, which hinders the region's development (JICA, 2012). According to JICA (2012) and Temu et al, (2013), Mwanza region has three trunk roads which also serve as the major communication links with the neighboring regions of Mara, Shinyanga and Kagera. They include: Mwanza to Shinyanga Road, Mwanza to Musoma Road, and Mwanza to Bukoba Road. All these roads start and end in Mwanza regional center town, which is seen as the most important link center of transport for the whole Lake Region Area (Table 2). 


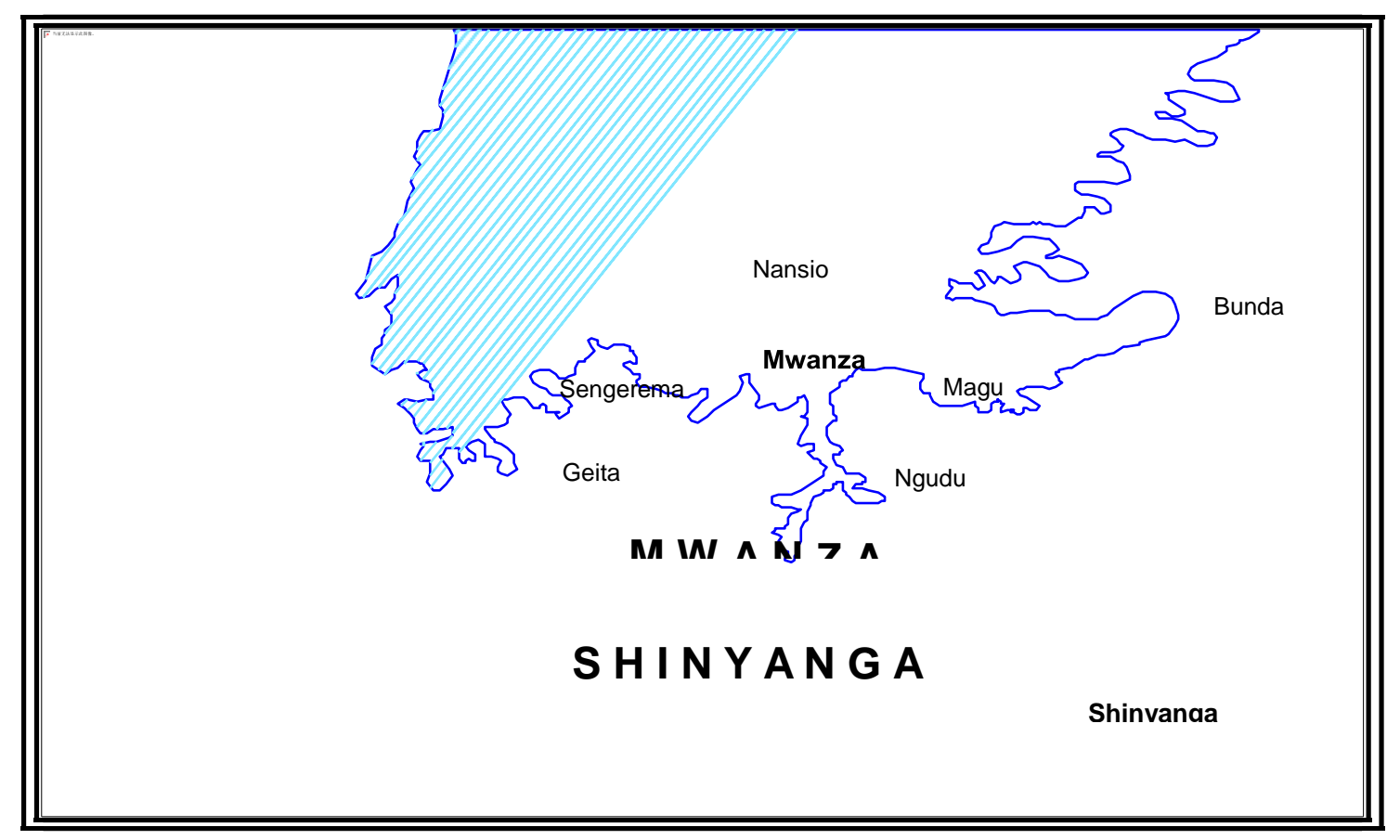

Figure 3. Road network map of Mwanza

Source: Google Maps.

Most of the roads in the region are of gravel and earth. There are only some few roads in Mwanza town and the Mwanza to Musoma trunk road that have been bitumenised, with only $139.5 \mathrm{~km}$ of such roads in the region (URT, 1999). The majority of the roads in the region are in urgent need of improved road surface, better drainage and more intensive maintenance (URT, 1999). Improvement of the road network as well as increasing total road length are very important in the opening up of new agricultural potential avenues, stimulating trade and making easy the movement of people (Temu et al., 2013). The main factors constraining food supply include the extreme state of roads linking to main centres and other such as traders, farmers and the cost of fuel (Limao \& Venable, 2000; Banjo et al., 2012). The agricultural sector in Mwanza needs to change by improving the conditions of rural roads. The region should strategise on farm mechanization, create new market opportunities for small-scale farmers and restructure its national tradition through innovation and improved yields for self-sufficiency in food (DFID, 2008). More emphasis needs to be placed on improvement of feeder roads as they do connect the majority of the people in rural areas with the rest of the region (Torero \& Chowdhury, 2005). One of the factors determining whether or not the agricultural sector grows is the conditions on the feeder roads and the availability of transport facilities. 


\section{Al Macrothink}

Table 2. Road network, length (Kms), type of road, distribution by regional districts

\begin{tabular}{|c|c|c|c|c|c|}
\hline \multirow[t]{2}{*}{ District } & \multicolumn{4}{|c|}{ Type of road } & \multirow{2}{*}{$\begin{array}{r}\text { Total } \\
(\mathrm{Kms})\end{array}$} \\
\hline & $\begin{array}{c}\text { Trunk Roads } \\
(\mathrm{Kms})\end{array}$ & $\begin{array}{c}\text { Regional Roads } \\
(\mathrm{Kms})\end{array}$ & $\begin{array}{c}\text { District Roads } \\
\mathrm{Kms})\end{array}$ & $\begin{array}{c}\text { Feeder Roads } \\
(\mathrm{Kms})\end{array}$ & \\
\hline Ukerewe & 0 & 110.0 & 255.0 & 0.0 & 365 \\
\hline Magu & 128.0 & 165.0 & 393.0 & 550.0 & 1,236 \\
\hline Mwanza & 33.5 & 132.0 & 695.5 & 0.0 & 861 \\
\hline Kwimba & 113.0 & 361.0 & 364.0 & 508.0 & 1,346 \\
\hline Sengerema & 78.0 & 286.0 & 428.0 & 232.0 & 1,024 \\
\hline Geita & 61.0 & 383.0 & 500.0 & 573.0 & 1,517 \\
\hline Total & 413.5 & $1,437.0$ & $2,635.5$ & $1,863.0$ & 6,349 \\
\hline
\end{tabular}

Source: URT (1999). Rolling Plan and Forward Budget 1997/98-1999/2000 Mwanza region.

Poor quality or non-improvement of feeder roads can result in crop spoilage, heavy stress on lorries with subsequent high transportation costs and low utilization of the transport capacity (Cook et al., 2017). Based on 2017 GDP figures, unpaved road networks in 10 wealthiest African countries are presented in Table 3.

Table 3. Unpaved roads in 10 wealthiest African countries - 2017

\begin{tabular}{|l|c|c|c|c|c|c|}
\hline Country & Area $(\mathrm{Km})$ & $\begin{array}{c}\text { Population } \\
2019\end{array}$ & $\begin{array}{c}\text { GDP }(2017) \\
(\mathrm{Bn} \$)\end{array}$ & $\begin{array}{c}\text { Total Road } \\
\text { Network Km }\end{array}$ & $\begin{array}{c}\text { Unpaved } \\
\text { Roads }\end{array}$ & $\begin{array}{c}\% \text { Unpaved } \\
\text { Roads }\end{array}$ \\
\hline Nigeria & 923,768 & $200,962,417$ & 376.284 & 193,200 & 164,220 & 85.0 \\
\hline South Africa & $1,221,037$ & $58,065,097$ & 349.299 & 747,014 & 588,062 & 78.7 \\
\hline Egypt & $1,001,449$ & $101,168,745$ & 237.037 & 137,430 & 10,688 & 7.8 \\
\hline Algeria & $2,381,741$ & $42,679,018$ & 178.287 & 113,655 & 26,050 & 22.9 \\
\hline Angola & $1,246,700$ & $31,787,566$ & 124.209 & 51,429 & 46,080 & 89.6 \\
\hline Morocco & 446,550 & $36,635,156$ & 109.824 & 58,395 & 17,279 & 29.6 \\
\hline Ethiopia & $1,104,300$ & $110,135,635$ & 80.874 & 110,414 & 96,060 & 87.0 \\
\hline Kenya & 580,367 & $52,214,791$ & 79.511 & 161,452 & 147,032 & 91.1 \\
\hline Sudan & $1,861,484$ & $42,514,094$ & 58.239 & 11,900 & 7,580 & 63.7 \\
\hline Tanzania & 945,203 & $60,913,557$ & 51.725 & 86,472 & 79,380 & 91.8 \\
\hline
\end{tabular}

Source: Ngezahayo et al. (2019).

The percentages of unpaved roads in table 3 suggest that these countries rely on unpaved roads for mobility, access to goods and services and related issues in rural areas. The more the percentages of poor road conditions, the poor socio-economic conditions affecting the rural area. The figures show that Tanzania has more unpaved roads $(91.8 \%)$, compared to Kenya (91.1\%), Angola (89,6\%), Ethiopia (87\%), Nigeria (85\%), South Africa (78.7\%), and Sudan (63.7). The remaining countries in the group have small percentages of unpaved roads. 


\subsection{Focus on Rural Mobility}

Rural roads are important in connecting rural people and to isolate them from poverty. Rural isolation can imprison the elderly and people with disabilities. The focus should be on people's mobility that facilitate exchange of ideas on how to achieve effective rural development given reliable rural transport. Mobility through rural roads helps rural households to be connected to markets for goods and services by remaining in their remote areas (Ngezahayo et al., 2019). Rural roads with high level of truck services linking to cities are crucial in achieving high impact of economic growth. As such, they should be in good conditions to enable truck fleet efficiency and competition in both passable secondary rural roads (Raballand, 2010). A positive impact of rural road networks should be aimed at maximising the participation of both men and women in development of rural communities, create development opportunities by involving those working on rural transport (Ngezahayo et al., 2019). Travel by rural household members is predominantly by walking with goods headloaded. The major portion of the rural transport burden falls on women. They are responsible for over $70 \%$ of transport in terms of time, and over $80 \%$ in terms of effort. An average female in Ghana spends 1,000 hours per annum solely on transport, and in Tanzania nearly 1,600 hours per annum (Harrison \& Howe, 1997).

\subsection{Improving, Maintaining and Constructing New Rural Roads}

Most rural communities depend on agriculture, livestock, fisheries and forestry for subsistence and income generation. Improved rural roads can provide economic justification for new investments in the construction and maintenance of rural roads. This includes increased agricultural production leading to increases in rural incomes (Knox et al., 2013). In terms of the benefits of rural roads construction and maintenance, many studies suggest that they correlate with lower input prices and freight costs (Ngezahayo et al., 2019), lead to increases in crop outputs (Lindsay \& Kongolo, 2014), increase cultivated farm areas (Ngila, 2007), while Escobal and Ponce (2002) reinforced the benefits of small rural roads in terms of enhanced agricultural production, employment, living standards and poverty reduction. The maintenance of rural roads is a heavy burden on many African governments. Although such maintenance of roads may only need the use of local labour and equipment, the lack of planning and/or funding impacts on the effectiveness of the maintenance (Ngezahayo et al., 2019). Involving rural people in labour-based road construction and maintenance related works is an evidence of providing them with valuable maximum pro-poor benefits of employment opportunities (Paudel, 2014; Starkey \& Hine, 2014); which helps them to improve education outcome, visit health facilities and fight high rate of poverty Lindsay and Kongolo (2014).

Where there are no roads, walking and carrying goods are the main means of land transport, with pack animals being important in some areas. People living four-hours walk from a market town (which is not uncommon) have to invest at least eight hours in transport in order to visit a market or services (Starkey \& Hine, 2014). This takes up valuable time and energy and makes it difficult for rural people to gain incomes from agriculture. The Medical literature on maternal mortality provides important key role of rural transport. Transport 


\section{Mll Macrothink}

infrastructure and means of transport including transport services in rural areas are both crucial to overcome the potentially fatal delays' in perinatal care (Starkey \& Hine, 2014). In the same way, improved and managed rural roads can greatly influence primary and secondary learners from rural areas to attend schools. In most countries, rural primary schools are within walking distances, but secondary schools are more spaced out, requiring much longer average journeys (Starkey \& Hine, 2014). Poor access to road transport in rural areas can be a major cause of perinatal mortality, with an estimated $75 \%$ of mortality resulting from inadequate transport to access basic health facilities.

The construction of a new rural road can lead directly to the construction of a new secondary school funded by a private foundation (Lindsay \& Kongolo, 2014). The study suggests an alternative low-cost intermediate means of transport that provides minimum level of improvement in rural transport, based on previous experience from other African countries of Burkina Faso, Ghana, Uganda Rwanda, Kenya, and Malawi (Table 4). It is believed that these means will impact travel for social and economic purposes that is rarely achieved through road improvements alone. Farmers can be provided with adequate means of transportation, such as a bicycle with a trailer and others to improve the efficiency on directly productive tasks (Guitink et al., 1994). The obvious limitation to this suggestion is that it can only be implemented in areas with appropriate roads. The estimate cost of constructing rural roads would be much more than the cost of providing bicycles with trailers to small farmers, including the cost of purchase, shipping and maintenance tools such as oil (Lindsay \& Kongolo, 2014).

Table 4. Alternative intermediate means of transport for rural areas

\begin{tabular}{|l|l|l|l|}
\hline Type of Intermediate Transport & Maximum Load & Maximum Speed & Maximum Range \\
\hline Wheelbarrow & 100 & 5 & 10 \\
\hline Bicycle & 75 & 20 & 20 \\
\hline Bicycle with trailer & 200 & $10-15$ & $15-20$ \\
\hline Bicycle and sidecar & 150 & $10-15$ & $15-20$ \\
\hline Pack animal & $100-250$ & 5 & $15-20$ \\
\hline Animal-drawn cart (Oxen) & $500-1500$ & 5 & $15-20$ \\
\hline Motorcycle & 100 & $40-90$ & 100 \\
\hline Motorcycle and sidecar & $250-500$ & $30-60$ & 60 \\
\hline Motorcycle and trailer & 250 & $30-60$ & 6 \\
\hline Single-axle tractor and trailer & 1500 & $15-20$ & 40 \\
\hline
\end{tabular}

Source: Lindsay and Kongolo, (2014).

Travel by rural household members is predominantly by walking with goods headloaded. Travel by motor vehicle is restricted to number of long-distance trips, usually for social, commercial and marketing reasons (Harrison \& Howe, 1997). 


\section{Conclusion and Recommendations}

\subsection{Conclusion}

Approach to improving rural roads is an important step to be taken toward agricultural and rural development. The main objective of this study was to re-emphasise the critical role played by rural roads as catalyst for rural and agricultural development (Warr, 2010). It is the only way leading to improvement of both quality of life and well-being of people in rural areas, including the provision of infrastructure, increased economic activities and agricultural production in rural areas (Warr, 2010; World Bank, 2019). Rural development concept encompasses the development of agriculture, village, industries and crafts, as well as socio-economic infrastructure, community services and facilities, and human resources in rural areas (Ale, 2013). It is the result of interactions between various physical, technological, economic, social, cultural and institutional factors, leading to improve the well-being of the rural people. Rural areas represent the engines for industrial and economic development in most countries, given their potential for agricultural products (World Bank, 2010). This study argued that importance of improving the quality of rural roads is to improve the quality of life of rural people, to support and enhance agricultural development and related socio-economic activities (Zhao \& Kanamori, 2007). It is also important given the role rural roads play in making food production and distribution easier and more efficient (Temu et al., 2014).

This study supports previous works that have shown that rural roads are critical in increasing economic activities leading to increases in rural incomes (Escobal \& Ponce, 2002; JICA, 2012; Ale, 2013; Starkey et al., 2014; Cook et al., 2017; and Ngezahayo et al., 2019). Such activities are often referred to as the least link of the transport network, that provide the most important link in terms of providing access and mobility of the rural population (Cuong, 2011). The lack of management impacts negatively on access to basic needs by rural communities. Whether one looks at agriculture or rural migration to urban, rural roads still play an important and a useful role (Faiz, 2012). Constructing a road in rural area would be more expensive than managing and maintaining the existing ones. Constructing a road alone does not help much rural communities, because transportation costs and economic conditions of the communities matter most. Overall, this study focused on the economic growth and development concepts to get rural people out of poverty (Guimaraes \& Uhl, 1997). The lessons learned from the literature on rural roads studies have contributed more to this study due to sufficient relevant information obtained from these studies.

\subsection{Recommendations}

In line with the findings of this study, the following have been recommended:

1) Regular maintenance and management of rural roads are pre-conditions to enhance the positive impact that rural roads can bring to rural communities.

2) Emphasis should be placed on minor maintenance, that need not be neglected, often due to lack of funds or little political willingness. 
3) Local authorities should be willing to strategise on how to authorise small and major rehabilitation of roads or reconstruction after a road has deteriorated.

4) Since the maintenance of rural roads is a heavy burden on many governments, local authorities should strategise on how to use cheap labour to do the work. Sometimes the maintenance may only need the use of local rural people and equipment, let no lack of planning and funding impacts negatively on the maintenance.

\section{References}

ADB. (2007). Rural Accessibility in the Asia and Pacific Region. Asian Development Bank Transport Strategy Final Report, January, IT Transport Limited. Ardngton.

Adeniyi, J. O., Akinrinmade, Y., \& Abiondun, A. L. (2018). Analysis of road transport impact on rural development In Nigeria: A Study on Akure North Local Government Area, Ondo State. International Journal of New Technology and Research, 4(3), 102-110.

Akinola, S. R. (2007). Coping with infrastructural deprivation through collective action among rural people in Nigeria. Nomadic Journal of African Studies, 16(1). 30-46.

Ale, A. S. (2013). Rural Transportation to Food Crop Production. Journal of Environment, 2(5), 112-117

Astalin, P. K. (2013). Qualitative research design: A Conceptual Framework. International Journal of Social Science \& Interdisciplinary, 2(1), 118-124.

Banjo, G. A., Gordon, H. F., \& Riverson, J. D. (2012). Rural transport: improving its contribution to growth and poverty reduction in Sub-Saharan Africa. Sub-Saharan Africa Transport Policy Program (SSATP) working paper series; no. 93. Washington DC: World Bank. Retrieved from http://documents.worldbank.org/curated/en/635271468193136281/Rural-transport-improving -its-contribution-to-growth-and-poverty-reduction-in-Sub-Saharan-Africa

Barker, T. L. (1994). Doing social research (2nd ed.). New York, McGraw-Hill.

Barret, C. B., Reardon, T., \& Webb, P. (2001). Non farm income diversification and household livelihood strategies in rural Africa: concepts, dynamics and policy implications. FoodPolicy, 26, 315-331. http://dx.doi.org/10.1016/S0306-9192(01)00014-8

Bogdan, R., \& Biklen, S. K. (2006). Qualitative Research for Education: An Introduction to Theories and Methods (5th ed.). London, UK: Pearson.

Buys, P., Deichmann, U., \& Wheeler, D. (2006). Road Network Upgrading and Overland Trade Expansion in Sub-Saharan Africa. Development Research Group, World Bank. http://dx.doi.org/10.1596/1813-9450-4097

Calvo, C. M. (1994). Case study on the role of women in rural transport: Access of women to domestic facilities. Sub-Saharan Africa Transport Policy Program (SSATP Working Paper No11), The World Bank and Economic Commission for Africa. Available at: http://documents.worldbankorg/curated/en/795551468767436598/pdf/272170PAPER0FR1r01 
e0r1le0des0femmes.pdf

Cook, J., Huizenga, C., Petts, R., Visser, C., \& AYiu, A. (2017). The Contribution of Rural Transport to Achieve the Sustainable Development Goals. Research Community for Access Partnership (ReCAP) **Partnership on Sustainable, Low Carbon Transport (SLoCaT). Retrieved from https://sustainabledevelopment.un.org/content/documents/16933

Corbin, J., \& Strauss, A. (2008). Basics of Qualitative Research: Techniques and Procedures for Developing Grounded Theory (3rd ed.). Thousand Oaks, CA: SAGE Publications

Csaki, C., \& Tuck, L. (2000). Rural Development Strategy; Eastern Europe and Central Asia. Washington DC, World Bank. Retrieved from http://documents.worldbank.org/

Cuong, N. V. (2011). Estimation of the impact of rural roads on household welfare in Vietnam. Asia-Pacific Development Journal, 18(2), 105-135.

Dercon, S., Gilligan, D., Hoddinott, J., \& Woldehanna, T. (2009). The Impact of Agricultural Extension and Roads on Poverty and Consumption Growth in Fifteen Ethiopian Villages. American Journal of Agricultural Economics, 91(4), 1007-1021. http://dx.doi.org/10.1111/j.1467-8276.2009.01325.x

DFID. (2008). Better roads for Africa, Research News Research for Development. Retrieved from http://www.dfid.gov.uk/r4d/news.asp?ArticleID=50292

Donngos, C., Edmonds, G., \& Johannessen, B. (2007). Rural roads maintenance: Sustaining the benefits of improved access. International Labour Organisation (ILO), Bangkok. Retrieved from http://www.ilo.org/wcmsp5/groups/public/---asia/---ro-bangkok/documents/publication/wcms _bk_pb_226_en.pdf

Escobal, J., \& Ponce, C. (2002). The benefits of rural roads: enhancing income opportunities for the rural poor. GRADE Working Paper 40. Grupo de Análisis para el Desarrollo (GRADE), Lima, Peru. 56p. from http://grade.org.pe/download/pubs/ddt/ddt40EN.pdf

Faiz, A. (2012). The Promise of Rural Roads. Review of the Role of Low-Volume Roads in Rural Connectivity, Poverty Reduction, Crisis Management, and Livability. Transportation $\begin{array}{llll}\text { Research } & \text { Circular } & \text { E-C167. } & \text { Retrieved }\end{array}$ http://onlinepubs.trb.org/onlinepubs/circulars/ec167.pdf

Guimaraes, A. L., \& Uhl, C. (1997). Rural transport in Eastern Amazonia: Limitations, options, and opportunities. Journal of Rural Studies, 13(4), 429-440. http://dx.doi.org/10.1016/S0743-0167(97)00019-3

Guitink, P., Holste, S., \& Lebo, J. (1994). Non-motorised transport: confronting poverty through affordable mobility. Infrastructure Notes, The World Bank. Transport No. UT- 4. Retrieved from http://www.worldbank.org/INTURBANKTRANSPORT../T-UT-4.pdf

Harrison, P., \& Howe, J. (1997). Measuring the transport demands of the rural poor: 
Experience from Africa. Humanity Development Library 2.0 for Sustainable Development and Basic Human Needs. Retrieved from http://www.nzdl.org/gsdlmod?

IFRTD. (2006). Intermediate Means of Transport. The International Forum for Rural Transport and Development. Retrieved from http://ifrtd.gn.apc.org/new/issues/imts.php

Jacoby, H. C. (2000). Access to markets and the benefits of rural roads. Economic Journal, 110(465), 713-737. http://dx.doi.org/10.1111/1468-0297.00562

Jacques, M., \& Wally, W. (2012). Got a road? The importance of a good road network. Retrieved from http://blogs.worldbank.org/africacan/got-a-road-the-importance-of-a-good-road-network

JICA. (2012). Data Collection Survey for Rural Roads Development/Maintenance in the United Republic of Tanzania, Final Report. Japan International Cooperation Agency (JICA) PADECO, Co Lmt. Retrieved from http://open_jicareport.jica.go.jp/pdf/12068516.pdf

Knox, J., Daccache, A., \& Hess, T. (2013). Systematic Review: What is the Impact of Infrastructural Investments in Roads, Electricity and Irrigation on Agricultural Productivity? Collaboration for Environmental Evidence, Bangor, UK. Retrieved from http://r4d.dfid.gov.uk/pdf/

Limao, N., \& Venable, A. J. (2000). Infrastructure, geographical disadvantage, transport costs and trade. World Bank Economic Review, 15(3), 451-479. http://dx.doi.org/10.1093/wber/15.3.451

Lindsay A. K., \& Kongolo, M. (2014). Rural Roads and Agricultural Development in Swaziland. Kamla-Raj Journal of Human Ecology, 48(3), 431-438 https://doi.org/10.1080/09709274.2014.11906814

Mwase, N. R. L. (2007). Role of transport in rural development in Africa, Foreign summaries. Journal of Transport Review, 73(2), 235-253. https://doi.org/10.1080/01441648908716726

Ngezahayo, E., Burrow, M., \& Ghataora, G. (2019). Rural Roads -roles, challenges and solutions for Sub-Saharan sustainable development. International Journal of Latest Engineering and Management Research, 4(10), $70-79$

Paudel, G. (2014). Influence of Roads on Socio-Economic Aspects of Rural People A case study of selected VDCs of Dailekh district. 3rd World Conference on Applied Sciences, Engineering \& Technology 27-29 September, Kathmandu, Nepal. Retrieved from http://www.basharesearch.com/ WCSET2014/wcset2014048.pdf

Raballand, G. (2010). Rural Road Investment Efficiency: Lessons from Burkina Faso, Cameroon, and Uganda. Retrieved from http://documents.worldbank.org/curated/en//372741468009614490/Rural-road-investment-eff iciency-lessons-from-Burkina-Faso-Cameroon-and-Uganda.

Sarkar, A. K. (2010). Key implementation issues-Sustainable rural roads maintenance in India. PIARC International Seminar, Hyderabad, Andhra Pradesh, India, 21-23 January. Retrieved 
from

https://www.piarc.org/en/activities/PIARC-International-Seminars-Proceedings/PIARC-Inter national-Seminars-2010/hyderabad_January10

Sossou, P., M'Paty, B., \& Buzika, F. (2011). Democatic Republic of Congo: Past. Present. Future? Civil society and the displaced persons of Bandundu. Coordinator and Accounts. Secretary of the BRP-Bandundu, DRC. Retrieved from http://www.fmreview.org/DRCongo/contents.htm

Starkey, P., \& Hine, J. (2014). Poverty and sustainable transport: How transport affects poor people with policy implications for poverty reduction. A literature review. UN Habitat, ODI, DFID, and UK AID. Retrieved from https://www.researchgate.net/publication/330855448

Temu, A. E., Nyange, D., Mattee, A. Z., \& Kashasha, L. K. (2005). Assessing rural services, infrastructure and their impact on agricultural production, marketing and food security in Tanzania. Final Donor Report. Retrieved from http://www.tanzaniagateway.org/docs/AssessingRuralServicesIandInfrastructureonAgricultur alProduction_Tanzania.pdf

Tighe, D. (2006). Roads and Poverty Reduction. Paper presented at the International Seminar on Rural Road Transport, Siem Reap, Cambodia, May, 15-16. Retrieved from http://www.ruralroads.org/doc/roadsandpovertyreduction.pdf

Torero, M., \& Chowdhury, S. (2005). Increasing access to infrastructure for Africa's rural poor. IFPRI: 2020 Africa Conference Brief. Workshop 16. Retrieved from ageconsearch.umn.edu/bitsrea-m/45763/2/ib32.pdf

URT. (1999). Mwanza Region Socio-Economic Profile. Joint Publication by: The Planning Commission Dar es Salaam and Regional Commissioner's Office Mwanza. Rolling Plan and forward Budget 1996/97 - 1998/99, Mwanza Region. The United Republic of Tanzania. Retrieved from http://www.tzonline.org/pdf/Mwanza.pdf

URT. (2013). 2012 Population and housing census - Population Distribution by Administrative Areas. National Bureau of Statistics Ministry of Finance Dar es Salaam and Office of Chief Government Statistician, President's Office. The United Republic of Tanzania. Retrieved from http://www.tzdpg.or.tz/fileadmin/documents/dpg_internal/dpg.pdf

Warr, P. (2010). Roads and Poverty in Rural Laos; An Econometric Analysis. Wiley Blackwell, 15(1), 152-16. DOI: 10.1111/j.1468-0106.2009.00494.x

World Bank. (2010). Rural Road Investment Efficiency Lessons from Burkina Faso, Cameroon, and Uganda. Directions in development, Infrastructure, Washington DC. Retrieved from http://documentsiteresources.worldbank.org/EXTRURALT/Resources/515369-12646058553 68investmentefficiency.pdf

World Bank. (2011). The problem with rural transport is that it is rural, the solution is in branding.

Retrieved

from 


\section{Macrothink}

Issues in Social Science

ISSN 2329-521X 2020, Vol. 8, No. 1

http://blogs.worldbank.org/transport/the-problem-with-rural-transport-is-that-it-is-rural-the-so lution-is-in-branding

World Bank. (2019). Rural Roads, Poverty, and Resilience Evidence from Ethiopia. Policy Research Working Paper 8800. World Bank Group, Poverty and Equity Global Practice. Retrieved from http://documents.worldbank.org/curated/en/220781554130465463/pdf/

Zhao, Z., \& Kanamori, T. (2007). Infrastructure and regional development in the People's Republic of China. Tokyo Asian Development Bank Institute Discussion Paper No.69. Available at http://www.adbi.org/discussion-paqper/2007/06/06/2279. prc.infra.rural

\section{Copyright Disclaimer}

Copyright for this article is retained by the author(s), with first publication rights granted to the journal.

This is an open-access article distributed under the terms and conditions of the Creative Commons Attribution license (http://creativecommons.org/licenses/by/3.0/). 